\title{
Implementasi Zakat Profesi di Lingkungan Pegawai Kantor Wilayah Kementerian Agama Provinsi Kalimantan Selatan
}

\section{Arif Mubarok}

Fakultas Ekonomi dan Bisnis Islam, Institut Agama Islam Negeri Palangkaraya, Indonesia. E-mail: mr.arif.me@gmail.com

\section{Dahlia}

Fakultas Ekonomi dan Bisnis Islam, Universitas Islam Negeri Antasari, Indonesia. E-mail: dahlialia2804@gmail.com

\begin{tabular}{|c|c|}
\hline ARTICLE INFO & ABSTRACT \\
\hline $\begin{array}{l}\text { Cara Sitasi: } \\
\text { Mubarok, Arif dan } \\
\text { Dahlia. } \\
\text { "Implementasi Zakat } \\
\text { Profesi di } \\
\text { Lingkungan Pegawai } \\
\text { Kantor Wilayah } \\
\text { Kementerian Agama } \\
\text { Provinsi Kalimantan } \\
\text { Selatan." At-Taradhi: } \\
\text { Jurnal Studi Ekonomi } \\
\text { 11, no. } 2 \text { (2020): 86- } \\
\text { 103. }\end{array}$ & $\begin{array}{l}\text { Studi ini bertujuan untuk menganalisis implementasi zakat profesi di } \\
\text { lingkungan PNS Kantor Wilayah Kementerian Agama Kalimantan Selatan } \\
\text { pasca diterbitkannya Surat Edaran No. KW.17.6/BA.03.2/177/2016 } \\
\text { tentang optimalisasi pengumpulan zakat pendapatan dan jasa, infaq, dan } \\
\text { shadaqah PNS melalui Unit Pengumpul Zakat. Penelitian ini menggunakan } \\
\text { metode pendekatan kualitatif deskriptif. Data diperoleh melalui wawancara } \\
\text { dan beberapa dokumen. Implementasi zakat profesi dianalisis melalui } \\
\text { perbandingan antara potensi dan penerimaan zakat profesi melalui Unit } \\
\text { Pengumpul Zakat Kantor Wilayah Kementerian Agama Kalimantan } \\
\text { Selatan. Hasil penelitian menyebutkan bahwa penerimaan zakat profesi di } \\
\text { lingkungan PNS Kanwil Kemenag Kalsel masih belum optimal, yakni } \\
\text { hanya 52,44\% di tahun } 2018 \text { dan } 54,29 \% \text { di tahun 2019. Tingkat } \\
\text { penerimaan zakat profesi yang masih rendah disebabkan perbedaan } \\
\text { penafsiran terkait ketetapan nishab dan kadar zakat. Ditambah lagi, surat } \\
\text { edaran yang diterbitkan berbentuk himbauan bukan aturan yang mengikat, } \\
\text { sehingga pegawai yang termasuk Muzakki seolah diberi kebebasan untuk } \\
\text { memilih menyalurkan zakatnya melalui UPZ atau tidak. Unit Pengumpul } \\
\text { Zakat juga dituntut untuk bersikap profesional guna membangun } \\
\text { kepercayaan Muzakki dengan cara meningkatkan kredibilitas, kedekatan } \\
\text { dalam bentuk komunikasi yang baik, dan handal dalam bekerja guna } \\
\text { memuaskan dan memudahkan Muzakki. }\end{array}$ \\
\hline
\end{tabular}




\section{Pendahuluan}

Zakat adalah harta yang wajib dikeluarkan oleh seorang muslim atau badan usaha untuk diberikan kepada yang berhak menerimanya sesuai dengan syariat Islam. ${ }^{1}$ Zakat memiliki dimensi dan fungsi sosial ekonomi dalam rangka pemerataan karunia Allah SWT serta perwujudan solidaritas sosial. Allah SW'T menyebutkan zakat beriringan dengan shalat sebanyak 72 kali dalam Al-Qur'an. ${ }^{2}$ Kalau sholat menjadi manifestasi rasa syukur atas nikmat Allah yang berupa kesehatan, maka zakat menjadi wujud syukur atas nikmat Allah yang berupa harta. ${ }^{3}$

Seiring berkembangnya fikih kontemporer, ranah cakupan zakat pun mengalami perluasan. Selain hadirnya konsep zakat perusahaan seperti, Yusuf Qardawi juga mengemukakan pendapatnya tentang konsep zakat pencarian dan profesi. Dalam UU No. 23 Tahun 2011 tentang Pengelolaan Zakat di antara hal yang wajib dizakati menurut Undang-undang tersebut adalah Zakat Pendapatan dan jasa yang juga dikenal sebagai Zakat Profesi, yakni bagian dari Zakat Mal yang wajib dikeluarkan atas harta yang berasal dari pendapatan / penghasilan rutin dari pekerjaan yang tidak melanggar syariah. ${ }^{4}$ Ulama salaf biasanya menyebut zakat profesi dengan al-mal al-mustafad. Kategori pendapatan dikenai zakat pendapatan seperti gaji pegawai negeri/swasta, konsultan, dokter, atau yang dihasilkan dari undian maupun kuis berhadiah yang tidak mengandung unsur judi. ${ }^{5}$

Konsep-konsep terkait perkembangan zakat pendapatan terkadang masih menimbulkan pro dan kontra, sehingga dalam pengimplementasiannya masih terhalang beberapa kendala. Pertanyaan yang sering kali hadir adalah apakah konsep tentang zakat profesi sudah sesuai dengan ruang dan waktu pengimplementasiannya, serta bagaimana kemampuan Amil dalam memahami konsep zakat profesi yang masih ada perbedaan penafsiran.

Jika berbicara implementasi zakat profesi, maka berkaitan pula dengan strategi agar potensi zakat pendapatan dapat terealisasi dengan optimal. Untuk mengoptimalkan realisasi potensi zakat profesi, perlu suatu regulasi/aturan yang jelas dan mengikat bagi seluruh warga negara Indonesia yang beragama Islam. Pada dasarnya regulasi tentang zakat memuat sejumlah ketentuan, sanksi, larangan, dan hal-hal lain seputar kegiatan pengelolaan zakat, sehingga diharapkan dapat terhindarkan dari praktik pengelolaan ilegal dan menyimpang. Muara dari pembentukan peraturan tersebut adalah terbentuknya suatu sistem pengelolaan zakat melalui lembaga yang profesional serta Amil yang bersikap amanah dalam mengelola dana zakat. Untuk melahirkan peraturan tentang zakat yang mengakomodir semua proses pengelolaan zakat tentu tidaklah mudah, hal ini membutuhkan sebuah proses yang cukup kompleks. ${ }^{6}$

\footnotetext{
1 Republik Indonesia, "Undang-Undang Republik Indonesia No. 23 Tahun 2011 Tentang Pengelolaan Zakat" (2011).

2 Yulia Hafizah, Dimensi Normatif Ekonomi Islam: Penjelasan Seputar Ayat-Ayat Ekonomi Dalam Al-Qur'an (Yogyakarta: Kurnia Kalam Semesta, 2017).

${ }^{3}$ M. Masykur Khoir, Risalah Zakat (Kediri: Duta Karya Mandiri, 2016).

${ }^{4}$ BAZNAS, “Zakat Penghasilan,” diakses 10 Desember 2020, https://baznas.go.id/zakatpenghasilan.

${ }^{5}$ Fakhruddin, Fiqh dan Manajemen Zakat di Indonesia (Malang: UIN-Maliki Pres, 2008).

${ }^{6}$ Widi Nopiardo, “Perkembangan Fatwa MUI Tentang Masalah Zakat,” Jurnal Ilmiah Syari'ab 15, no. 1 (2016): 66-76.
} 
Dalam rangka melaksanakan UU No. 23 Tahun 2011 terkait pengumpulan Zakat pendapatan dan jasa, maka Pemerintah mengeluarkan Peraturan Pemerintah No. 14 Tahun 2014 tentang Pelaksanaan UU No. 23 Tahun 2011 serta Instruksi Presiden No. 3 Tahun 2014 tentang Optimalisasi Pengumpulan Zakat di Kementerian/Lembaga, Sekretariat Jenderal Komisi Negara, Pemerintah Daerah, BUMN, BUMD melalui BAZNAS. Atas peraturan-peraturan tersebut, beberapa Kantor Pemerintahan mengeluarkan Surat Edaran agar Aparatur Sipil Negara, salah satu di antaranya adalah Kantor Wilayah Kementerian Agama Kalimantan Selatan mau membayarkan zakat profesinya melalui Unit Pengumpul Zakat.

Kantor Wilayah Kementerian Agama Kalimantan selatan menunjukkan keseriusannya dalam melaksanakan amanat UU No. 23 Tahun 2011 melalui Surat Edaran nomor KW.17.6/BA.03.2/177/2016, tentang optimalisasi pengumpulan zakat, infaq, dan shadaqah karyawan/karyawati melalui Unit Pengumpul Zakat (UPZ). Kemudian dana zakat, infaq dan shadaqah yang terkumpul disetorkan ke BAZNAS sesuai dengan tingkatannya. Sebagai instansi pemerintah yang mengatur urusan-urusan agama guna kemaslahatan masyarakatnya, pantaslah jika Kementerian Agama menjadi contoh dalam pengimplementasian zakat pendapatan. Oleh sebab itu, perlu dilakukan evaluasi atas pengimplementasian pengembangan konsep zakat profesi Pegawai Negeri Sipil Kantor Wilayah Kementerian Agama Provinsi Kalimantan Selatan. Penelitian ini akan menganalisa potensi penerimaan zakat pendapatan atas dasar nisab emas dengan harga yang berlaku pada tahun 2018 dan 2019, serta realisasi penerimaan zakat atas dasar strategi yang dilakukan Unit Pengumpul Zakat di dalam lingkungan kantor.

\section{Landasan Teori}

\section{Zakat Profesi dan Regulasinya di Indonesia}

Zakat profesi adalah zakat yang dikenakan terhadap penghasilan atau pendapatan yang diperoleh oleh seseorang sebagai imbalan atas pekerjaan yang ia usahakan secara sendiri maupun bersama-sama. ${ }^{7}$ Sebagian ulama mutaakkhirin beranggapan bahwa penghasilan/pendapatan dari sebuah profesi termasuk dalam harta yang wajib dikeluarkan zakatnya. Setiap harta seorang muslim yang mencapai atau lebih dari satu nishab maka ada hak orang lain di dalam harta tersebut. Yusuf Al-Qaradhawi menyebutnya sebagai "al-mal al-mustafad" (harta yang diambil faidah), sedangkan Wahbah Al-Zuhaili menamakannya "Zakat kasbi al-amal wa al-miban al-burrah (harta hasil pekerjaan dan profesi bebas). ${ }^{8}$

Dasar dalam penetapan zakat profesi dapat dilihat sejak zaman Rasulullah SAW dan para sahabat serta para tabi'in. Rasulullah SAW menetapkan kepada 'Uttab bin Asid yang saat itu menjadi Gubernur Mekkah untuk menyisihkan sebanyak dua dirham setiap hari ke baitul maal. Utsman bin Affan juga menetapkan zakat atas setiap upah atau gaji yang diberikan kepada pegawainya selama sampai pada nishab. Selanjutnya, Mu'awiyah bin Abi Sofyan ketika menjadi khalifah juga menetapkan zakat atas tiap-tiap upah. Sementara Umar bin Abd al-'Aziz selalu mengambil zakat setiap kali menggaji pegawainya. Beliau juga mengambil zakat dari harta-harta yang

\footnotetext{
${ }^{7}$ Yusuf Qardawi, Figh Az-Zakah, Kedua (Mu'assisah Ar-Risalah, 1973).

${ }^{8}$ Khoir, Risalab Zakat.
} 
pernah disita pemerintah yang dikembalikan kepada pemiliknya dan mengambil zakat dari setiap upah yang ia berikan kepada seseorang. ${ }^{9}$

Hingga saat ini, beberapa negara Islam telah menetapkan ketentuan zakat profesi, salah satunya adalah Arab Saudi. Kerajaan Saudi Arabia mewajibkan zakat atas segala jenis penghasilan, baik berupa laba atau pendapatan, baik secara perseorangan ataupun syarikat, baik perdagangan, perusahaan maupun kerja perseorangan. Dewan Kajian dan Fatwa Kerajaan Saudi Arabia melalui Fatwa no 282, tanggal 11 Oktober tahun 1392 menyatakan wajib zakat atas seseorang yang memiliki uang yang sudah mencapai nishab, seperti seorang pegawai yang mendapatkan gaji bulanan. ${ }^{10}$

Di Indonesia sendiri sejak tahun 1951 s.d. 2017 terdapat berbagai peraturan tentang zakat, mulai dari Peraturan Menteri, Peraturan Presiden, Peraturan Pemerintah hingga Undang-undang. Namun Undang-undang tentang pengelolaan zakat baru lahir pada tahun 1999, yakni Undang-undang Nomor 38 Tahun 1999 tentang Pengelolaan Zakat direvisi untuk mencapai optimalisasi pengelolaan zakat di Indonesia. Hasil dari revisi tersebut adalah diterbitkannya UU No. 23 Tahun 2011 Tentang Pengelolaan Zakat. Kemudian diterbitkan juga PP No. 14 Tahun 2014 tentang Pelaksanaan UndangUndang Pengelolaan Zakat, serta Instruksi Presiden (Inpres) No. 3 Tahun 2014 tentang Optimalisasi Pengumpulan zakat di Kementerian/Lembaga, Sekretariat Jenderal Lembaga Negara, Sekretariat Jenderal Komisi Negara, Pemerintah Daerah, Badan Usaha Milik Negara, dan Badan Usaha Milik Daerah Melalui Badan Amil zakat Nasional. ${ }^{11}$

Melalui ketetapan UU No. 23 Tahun 2011 Pemerintah Indonesia meregulasi pengelolaan zakat di antaranya adalah zakat profesi. Pada Pasal 4 ayat 2 huruf h bahwa penghasilan atas pendapatan dan jasa termasuk dalam zakat mal yang wajib dikeluarkan zakatnya. Ditambah lagi dengan adanya Peraturan Menteri Agama (PMA) Republik Indonesia Nomor 52 Tahun 2014 tentang Syariat dan Tata Cara Penghitungan Zakat Mal dan Zakat Fitrah serta Pendayagunaan Zakat Untuk Usaha Produktif, di mana pada pasal 26 menetapkan besaran Nisab zakat pendapatan senilai $653 \mathrm{~kg}$ gabah atau $524 \mathrm{~kg}$ beras dengan kadar zakat senilai 2,5\%. Selain itu, dalam pasal 27 disebutkan pula bahwa zakat pendapatan dan jasa ditunaikan pada saat pendapatan dan jasa diterima dan dibayarkan melalui amil zakat resmi.

Sebagian ulama men-qiyas-kan nishab zakat profesi terhadap zakat pertanian (zuru") dan dengan perdagangan (tijarah). Karena ada kesamaan antara keduanya, yaitu samasama hasil dari sebuah pekerjaan. ${ }^{12}$ Yusuf Qardawi dalam bukunya menyebutkan bahwa nisab Zakat profesi jika di-qiyas-kan dengan zakat pertanian sebesar $653 \mathrm{~kg}$ gabah atau $524 \mathrm{Kg}$ beras. Besaran/kadar zakat penghasilan yang diperoleh dari modal saja atau dari modal kerja seperti penghasilan pabrik, gedung, percetakan, hotel. mobil, kapal terbang dan sejenisnya, maka besaran zakatnya adalah sepersepuluh

\footnotetext{
9 Puskas BAZNAS RI, "Ketentuan Dan Tata Cara Penghitungan Zaat Profesi/Penghasilan," no. 17/08/BR/VII/2017 (2017).

${ }^{10}$ Puskas BAZNAS RI.

${ }^{11}$ Nopiardo, "Perkembangan Fatwa MUI Tentang Masalah Zakat."

${ }^{12}$ Khoir, Risalab Zakat.
} 
atau 10\% dari pendapatan bersih setelah biaya, utang, dan kebutuhan pokok lainnya. Besaran/kadar ini berdasarkan qiyas pada penghasilan dari hasil pertanian yang diairi tanpa ongkos tambahan. Tetapi untuk pendapatan yang diperoleh dari pekerjaan saja seperti pendapatan pegawai dan golongan profesi yang mereka peroleh dari pekerjaan mereka, maka besar zakat yang wajib dikeluarkan adalah seperempat puluh atau $2,5 \% .{ }^{13}$

Majelis Ulama Indonesia melalui Fatwa MUI No. 3 Tahun 2003 memutuskan jika nishab zakat profesi di-qiyas-kan dengan nishab zakat emas dan perak yakni setara 85 gram emas dengan kadar sebesar 2,5\%. Waktu pengeluaran zakat profesi adalah pada saat menerima gaji jika sudah cukup nishabnya (setiap menerima gaji), atau jika tidak mencapai nishab maka semua penghasilan dikumpulkan selama 1 tahun, kemudian zakat dikeluarkan jika penghasilan bersihnya sudah cukup nishab. kemudian perhitungannya diakumulasikan atau dibayar di akhir tahun sebesar 2,5\%. ${ }^{14}$

\section{Potensi dan Implikasi Zakat Terhadap Perekonomian}

BAZNAS pada setiap tingkatannya dapat membentuk Unit Pengumpul Zakat (UPZ) pada setiap instansi pemerintah maupun swasta, dan kantor perwakilan Republik Indonesia baik di dalam maupun luar negeri. ${ }^{15}$ Unit Pengumpul Zakat (UPZ) adalah satuan organisasi yang dibentuk oleh BAZNAS untuk membantu pengumpulan zakat. Peran UPZ dalam penggalian potensi zakat profesi yaitu dengan mengoptimalkan pengumpulan zakat profesi di instansi masing-masing. Sedangkan distribusi zakat profesi dilakukan oleh BAZNAS sesuai dengan fungsinya menurut Undang-Undang No. 23 Tahun 2014 Pasal 7 yaitu, BAZNAS berfungsi melakukan perencanaan, pelaksanaan, dan pengendalian dalam pengumpulan, pendistribusian, dan pendayagunaan zakat, serta melakukan pelaporan dan pertanggungjawaban pelaksanaan pengelolaan zakat.

Sistem distribusi zakat mempunyai tujuan peningkatan kesejahteraan masyarakat dalam hal perekonomian, sehingga terjadi perubahan dari Mustahik menjadi Muzakki. ${ }^{16}$ Oleh sebab itu, pola distribusi zakat dipengaruhi oleh jumlah penerimaan zakat itu sendiri. Pemanfaatan zakat harus selektif, artinya ada pembagian yang memang ditujukan untuk kebutuhan konsumtif dan ada pembagian untuk kegiatan produktif, agar zakat yang terdistribusi berdaya guna. ${ }^{17}$ Menurut Qodri Azizy, pemanfaatan zakat untuk hal konsumtif lebih ditekankan ketika keadaan darurat, seperti apabila Mustahik tidak memungkinkan dibimbing untuk memiliki usaha produktif, atau ketika Mustahik memiliki kebutuhan mendesak. ${ }^{18}$ Analisis terhadap zakat dari sudut pandang ekonomi mengharskan adanya penyempurnaan terhadap implementasi pengelolaan zakat. Efektifitas pendistribusian zakat perlu ditinjau

\footnotetext{
${ }^{13}$ Yusuf Qardawi, Hukum Zakat, ed. oleh Salman Harun, Didin Hafidhuddin, dan Hasanuddin, 7 ed. (Bogor: Pustaka Litera AntarNusa, 2004).

${ }^{14}$ Majelis Ulama Indonesia, "Fatwa MUI Zakat Penghasilan,” Himpunan Fatwa MUI 3 (2003): 1-5.

${ }^{15}$ Republik Indonesia, Undang-Undang Republik Indonesia No. 23 Tahun 2011 Tentang Pengelolaan Zakat.

${ }^{16}$ Mursyidi, Akuntansi Zakat Kontemporer (Bandung: Remaja Rosdakarya, 2003).

${ }^{17}$ Fakhruddin, Fiqh dan Manajemen Zakat di Indonesia.

${ }^{18}$ Lailiyatun Nafiah, "Pengaruh Pendayagunaan Zakat Produktif Terhadap Kesejahteraan Mustahiq Pada Program Ternak Bergulir Baznas Kabupaten Gresik,” el-Qist V, no. 01 (2015): 307-21.
} 
ulang, baik itu program, jumlah/nominal, dan juga cakupan distribusinya. Sehingga dampak zakat terhadap perekonomian dapat dirasakan oleh setiap pelaku ekonomi terutama Mustahik. ${ }^{19}$

Temuan dalam sebuah penelitian menyebutkan bahwa pendayagunaan zakat semakin nampak kontribusinya dalam mendukung upaya pemerintah untuk mengentaskan kemiskinan. Zakat tersebut difokuskan bagi ashnaf fakir miskin dan dialokasikan pada sektor sosial kemanusiaan dan pendidikan. Implikasi dari temuan ini adalah optimalisasi potensi zakat akan mampu menghadirkan kesejahteraan ekonomi bagi masyarakat yang tentunya didorong dengan partisipasi seluruh elemen bangsa. ${ }^{20}$ Beberapa Mustahik pasca menerima zakat terutama dalam bentuk zakat produktif, dalam hal pendapatan mengalami peningkatan dari sebelum menerima bantuan zakat produktif. ${ }^{21}$ Bukan hanya di Indonesia, program pengentasan kemiskinan di Sudan melalui pemberdayaan zakat yang dikelola oleh salah satu Lembaga Amil Zakat di Sudan yakni Sudanese Zakah Chamber (SZC) menunjukkan dampak positif dan signifikan. ${ }^{22}$

Semakin banyak zakat yang diterima dan didistribusikan, maka akan semain besar kesempatan untuk meningkatkan kesejahteraan masyarakat salah satunya dalam hal pendapatan. Terdapat pengaruh positif signifikan dari jumlah dana yang disalurkan terhadap pendapatan Mustahik. ${ }^{23}$ Oleh sebab itu, potensi zakat harus terserap dengan optimal. Namun, sejauh ini potensi zakat di Indonesia belum terserap dengan optimal. Dengan potensi sebesar 462 triliun rupiah pada tahun 2017, jumlah zakat, infaq, dan sedekah yang terserap baru 6,2 triliun rupiah. ${ }^{24}$ Meskipun mengalami peningkatan sekitar 24\% dari penghimpunan tahun 2016, akan tetapi jumlah tersebut masih terbilang kecil dibandingkan potensinya yakni sekitar 1,3\% saja. Berbagai permasalahan menjadi kendala sulitnya merealisasikan potensi penerimaan zakat. Sosialisasi, ketegasan dan kemudahan pembayaran zakat perlu diwujudkan melalui regulasi zakat yang bukan lagi berbentuk himbauan. Jika potensi zakat terealisasikan dengan optimal, setidaknya satu kendala dalam pendayagunaan zakat terselesaikan.

\section{Kepatuhan dan Kesadaran Membayar Zakat Profesi}

Penyerapan zakat di Indonesia yang hanya mencapai 1,3\% saja dari potensi yang ada merupakan suatu pelajaran, dimana masih banyak masyarakat muslim yang belum sadar akan kewajiban berzakat. Mengingat sebanyak $87 \%$ penduduk

${ }_{19}$ Bank Indonesia dan Fakultas Ekonomi UII, Pengelolaan Zakat Yang Efektif: Konsep dan Praktik di Beberapa Negara, Seri Ekonomi Dan Keuangan Syariah (Jakarta: Departemen Ekonomi dan Keuangan Syariah Bank Indonesia, 2016).

${ }^{20}$ Nurwati Nurwati dan Heni Hendrawati, “Zakat dan Upaya Mengentaskan Kemiskinan,” Cakrawala: Jurnal Studi Islam 14, no. 1 (2019): 40-47, https://doi.org/10.31603/cakrawala.v14i1.2695.

${ }^{21}$ S. Utami dan I. Lubis, "Pengaruh Pendayagunaan Zakat Produktif Terhadap Pemberdayaan Mustahiq di Kota Medan,” Jurnal Ekonomi dan Keuangan, 2014.

${ }^{22}$ Khalifa Hassanain dan Abd elrahman Elzahi Saaid, "Zakah for Poverty Alleviation: Evidence from Sudan," International Research Journal of Finance and Economics, 2016.

${ }_{23}$ Mila Sartika, "Pengaruh Pendayagunaan Zakat Produktif terhadap Pemberdayaan Mustahiq pada LAZ Yayasan Solo Peduli Surakarta," La_Riba, 2008, https://doi.org/10.20885/lariba.vol2.iss1.art6.

${ }^{24}$ BAZNAS, Statistik. Zakat Nasional 2017, Badan Amil Zakat Nasional, 2018. 
Indonesia merupakan umat Islam, bahkan negara dengan penduduk beragama Islam terbanyak di dunia, hal ini menjadi permasalahan penting untuk diperhatikan. Sudah jelas Allah SW'T memerintahkan umat Islam untuk menunaikan zakat, dalam surah Al-Baqarah ayat 43;

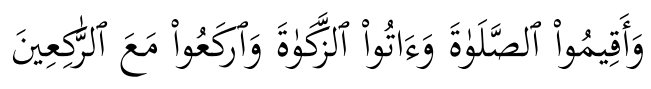

Artinya: "Dan dirikanlah shalat, tunaikanlah zakat dan ruku'lab beserta orang-orang yang ruku."

Rasulullah SAW pun telah mengingatkan bahwa salah satu landasan dalam Islam adalah zakat, sehingga tidak lengkap keislaman seseorang jika ia lalai menunaikan zakat.

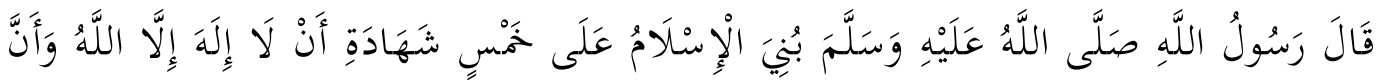

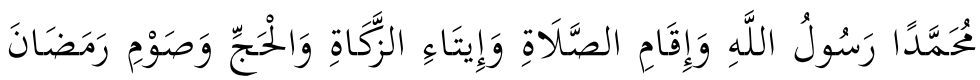

Artinya: "Rasulullah $S A W$ bersabda, Islam dibangun di atas lima (landasan); persaksian tidak ada ilah selain Allah dan sesungguhnya Mubammad utusan Allah, mendirikan shalat, menunaikan zakat, haji dan puasa Ramadhan."25

Zakat diwajibkan atas muslim yang mampu secara finansial. Untuk zakat profesi kemampuan tersebut diukur dari perbandingan jumlah pendapatan dengan nishab yang telah ditentukan. Namun disayangkan kesadaran masyarakat untuk membayar zakat mal maupun zakat penghasilan masih lebih rendah ketimbang kesadaran untuk membayar zakat fitrah. ${ }^{26}$ Jika dilihat secara manfaat, zakat fitrah hanya dapat dirasakan menjelang Idul Fitri dalam bentuk bahan makan pokok seperti beras atau gandum. Sedangkan zakat mal memiliki manfaat yang besar sebab yang dikeluarkan adalah harta kekayaan yang dapat didistribusikan lagi melalui program pemberdayaan zakat produktif. Dalam sebuah penelitian disebutkan bahwa kesadaran masyarakat untuk membayar zakat mal lebih rendah ketimbang zakat fitrah.

Terdapat faktor eksternal dan internal yang dapat memengaruhi Mustahik untuk mengeluarkan zakat. Adapun faktor eksternal yang mendorong tingkat kepatuhan Muzakki untuk menunaikan zakat antara lain profesionalitas Amil baik pada Lembaga Amil Zakat Nasional maupun Swasta. Profesionalitas seorang Amil diukur dari sikap transparansi, sosialisasi, serta keteraturan administrasi, sehingga preferensi Muzakki terhadap Lembaga Amil Zakat akan meningkat. ${ }^{27}$ Sedangkan faktor internal yang berpengaruh antara lain faktor pendidikan, religiusitas, dan pendapatan Mustahik. Tingkat pendidikan Mustahik dapat memengaruhi pola pikir Mustahik dalam memahami aturan dalam zakat. Tingkat religiusitas mempengaruhi Mustahik untuk mengeluarkan zakat, karena religiusitas berhubungan dengan pengabdian seorang

\footnotetext{
25 Salnatera, "Kitab 9 Imam," dalam Ensiklopedi Hadits (Google Play Store, 2015).

26 Herfita Rizki Hasanah Gurning dan Haroni Doli Hamoraon Ritonga, “Analisis Tingkat Kesdara Masyarakat Kecamatan Medan Baru Dalam Membayar Zakat,” Jurnal Ekonomi Dan Keuangan 3, no. 7 (2015): 490-504.
}

27 Ahmad Mukhlis dan Irfan Syauqi Beik, "Analisis Faktor-faktor yang Memengaruhi Tingkat Kepatuhan Membayar Zakat: Studi Kasus Kabupaten Bogor,” Al-Murara'ah 1, no. 1 (2013): 83-106, https://doi.org/10.29244/jam.1.1.83-106. 
hamba kepada Tuhannya. Kemudian, tingkat pendapatan juga menjadi faktor penting yang dapat memengaruhi kesadaran Mustahik mengeluarkan zakat, karena besaran pendapatan Mustahik berpengaruh terhadap nishab dan kadar zakat yang akan dibayarkan. ${ }^{28}$

\section{Metode Penelitian}

Penelitian ini menggunakan metode kualitatif deskriptif. Subjek dalam penelitian ini adalah Unit Pengumpul Zakat (UPZ) di Kantor Wilayah Kementerian Agama Provinsi Kalimantan Selatan. Sedangkan objek penelitian adalah Implementasi Zakat Profesi. Data yang digunakan adalah data primer dan data sekunder. Data primer diperoleh dari wawancara dengan informan yakni pengelola Unit Pengumpul Zakat dan beberapa karyawan yang dianggap mumpuni untuk memberikan data. Sedangkan data sekunder diperoleh dari laporan, catatan, atau dokumen yang dirasa mendukung analisis dalam penelitian ini.

Dalam proses penghimpunan data, potensi zakat profesi akan ditentukan atas dasar besaran gaji per tahun menggunakan nominal gaji rata-rata PNS golongan III. Penggunaan acuan tersebut karena sebagian besar PNS berada pada golongan III. ${ }^{29}$ Setelah semua data terkumpul maka dilakukan pengolahan data guna memperoleh kesimpulan dalam penelitian.

\section{Hasil Penelitian}

\section{Implementasi Zakat Profesi di Lingkungan pegawai Kantor Wilayah Kementerian Agama Provinsi Kalimantan Selatan}

Regulasi Zakat pada dasarnya telah ada sejak proses turunnya Islam, tersebutkan dalam AlQuran dan Hadits, bersifat wajib lagi mengikat bagi setiap muslim yang mampu secara finansial. Hingga Islam telah sempurna dan Indonesia menjadi negara dengan penduduk beragama Islam terbanyak di dunia, regulasi tersebut tetap mengikat dan mewajibkan setiap muslim yang mampu secara finansial mengeluarkan zakat.

Melalui PP No. 14 Tahun 2014 tentang Pelaksanaan UU No. 23 Tahun 2011, serta Inpres No. 3 Tahun 2014, pemerintah meregulasi sistem zakat di Indonesia, dan sebagai bentuk keseriusan pemerintah dalam upaya mengoptimalkan penyerapan potensi zakat di Indonesia. Beberapa Instansi Pemerintahan mengeluarkan himbauan sebagai bentuk implementasi zakat profesi, seperti yang dilakukan Kanwil Kemenag Kalsel melalui Surat Edaran nomor KW.17.6/BA.03.2/177/2016 tentang optimalisasi pengumpulan zakat profesi, infaq, dan shadaqah PNS di lingkungan Kantor melalui Unit Pengumpul Zakat (UPZ).

Dengan dikeluarkannya Surat Edaran nomor KW.17.6/BA.03.2/177/2016, setiap bulan Pegawai Negeri Sipil diberikan Blanko Zakat, Infaq, dan Shodaqoh untuk diisi. Bagi pegawai yang bersedia membayarkan zakat penghasilannya melalui Unit Pengumpul Zakat akan diberikan Nomor Pokok Wajib Zakat (NPWZ) oleh BAZNAS

\footnotetext{
28 Alvira 'Aina A'yun, “Analisis Faktor Tingkat Pendidikan, Religiusitas dan Pendapatan Dalam Mempengaruhi Kepatuhan Individu Mengeluarkan Zakat Maal (Studi Kasus Pegawai di Kementerian Agama Malang)," Jurnal Ilmiah Mahasiswa FEB Universitas Brawijaya 5, no. 2 (2017).

${ }^{29}$ Puskas BAZNAS RI, Indikator Pemetaan Potensi Zakat (IPPZ), 2019.
} 
dan langsung dipotong dari gajinya setiap bulan. Pemerintah pun berharap dengan adanya regulasi seperti ini setidaknya penyerapan potensi zakat di lingkungan Pegawai Negeri Sipil dapat dioptimalkan.

Namun surat edaran ini hanya bersifat himbauan, sehingga masih terdapat opsi bagi PNS untuk menolak membayarkan zakat profesinya melalui UPZ. Padahal jika surat edaran tersebut bersifat mengikat bagi setiap pegawai pun tidak masalah, sebab dasar syariat atas zakat adalah wajib. Dalam Al-Qur'an Surah At-Taubah/9:103 Allah berfirman:

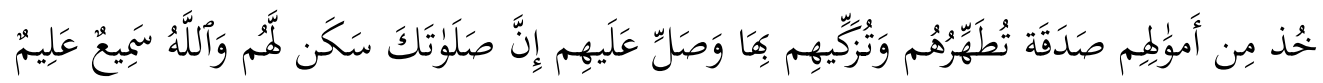

Artinya: "Ambillah zakat dari sebagian harta mereka, dengan qakat itu kamu membersibkan dan mensucikan mereka dan mendoalab untuk mereka. Sesunggubnya doa kamu itu (menjadi) ketenteraman jiwa bagi mereka. Dan Allah Maha Mendengar lagi Maba Mengetabui."

Ibnu Katsir memberikan tafsirnya atas ayat tersebut yakni Allah Subhanahu wa Ta'ala memerintahkan Rasul-Nya untuk mengambil zakat dari harta mereka guna membersihkan dan menyucikan (harta) mereka melalui zakat, infaq ataupun sedekah. ${ }^{30}$

Penerapan syariat harus dengan sikap tegas, dan bentuk ketegasan tersebut direalisasikan melalui regulasi zakat. Regulasi yang tepat akan memberikan dampak terhadap optimalisasi penyerapan potensi zakat. Indonesia adalah negara dengan potensi penerimaan zakat terbesar di dunia, sebab sekitar $87 \%$ penduduknya beragama Islam. menyebutkan bahwa potensi zakat di Indonesia adalah sekitar 217 triliun rupiah yang dihitung dari berbagai sumber, di antaranya dari penghasilan (profesi) dan perusahaan. Besar potensi ini setara dengan 3,4\% PDB Indonesia pada tahun 2010. ${ }^{31}$ Potensi penghimpunan zakat dapat mencapai 3,4\% dari total PDB apabila zakat ditetapkan sebagai pengurang pajak. ${ }^{32}$

Pada tahun 2017 potensi zakat telah mencapai 462 triliun rupiah atau mengalami peningkatan sebesar $113 \%$ dalam rentang waktu 5 tahun. ${ }^{33}$ Potensi zakat yang begitu besar nyatanya masih belum bisa terserap secara optimal, yakni baru 6,2 triliun rupiah. ${ }^{34}$ Meskipun penghimpunan pada tahun 2017 mengalami peningkatan sebanyak $24 \%$ dari tahun 2016, tetapi jumlah tersebut masih terbilang kecil dibandingkan potensinya yakni sekitar 1,3\% saja. Berbagai permasalahan menjadi kendala sulitnya merealisasikan potensi penerimaan zakat. Sosialisasi, ketegasan dan kemudahan pembayaran zakat perlu diwujudkan melalui regulasi zakat yang bukan lagi berbentuk himbauan, melainkan sebuah keharusan. Jika potensi zakat terealisasikan dengan baik, setidaknya satu permasalahan dalam penghimpunan dana zakat dapat teratasi.

\footnotetext{
${ }^{30}$ Muslim Media, “Tafsir Ibnu Katsir” (Penajam Paser Utara: Google Play Store, 2017).

31 Muhammad Firdaus dkk., "Economic estimation and determinations of Zakat potential in Indonesia," IRTI Working Paper Series, 2012.

32 Bambang Sudibyo, Prospek dan Tantangan Pembangunan Zakat 2019 (Jakarta: BAZNAS, 2018).

33 Puskas BAZNAS RI, Outlook Zakat Indonesia 2019 (Jakarta: Pusat Kajian Strategis Badan Amil Zakat Nasional, 2019).

${ }^{34}$ BAZNAS, Statistik Zakat Nasional 2017.
} 
Pemanfaatkan zakat sebagai sumber pendapatan negara guna peningkatan kesejahteraan telah dilakukan sejak masa Rasulullah shalallahu'alaihi wa sallam, dan terbukti berhasil ditandai dengan tercapainya puncak kejayaan Islam. Sejarah mencatat puncak kejayaan Islam atau yang lebih dikenal sebagai The Golden Age of Islam terjadi antara tahun 786 hingga 833 Masehi, yakni pada masa kepemimpinan Harun al-Rasyid dan putranya al-Ma'mun di era Bani Abbasiyah. Kekayaan yang melimpah pada masa ini digunakan untuk kegiatan-kegiatan di berbagai bidang sosial, pendidikan, kebudayaan, pendidikan, ilmu pengetahuan, kesehatan, kesusastraan dan pembangunan fasilitas-fasilitas umum. $^{35}$

Zakat, infaq dan sedekah hanyalah sebagian dari beberapa instrumen pendapatan negara dalam Islam, tetapi potensi dari ketiga instrumen tersebut sangatlah besar. Oleh sebab itu, implementasi zakat profesi memerlukan regulasi yang jelas dan tegas, bukan sekedar himbauan. Sebab hukum syariat dari zakat itu sendiri adalah wajib bagi mereka yang mampu, maka pemerintah berhak untuk menarik kewajiban atas para wajib zakat. Pengawasan berkala juga perlu dilakukan agar implementasi zakat profesi sesuai dengan regulasi yang ditetapkan. Bentuk Pengawasan dalam Implementasi Zakat Profesi di lingkungan Kanwil Kemenag Kalsel dilakukan dengan pembukuan dana yang masuk melalui UPZ kemudian diolah pelaporan dan ditanda tangani oleh Ketua UPZ (Kepala Bidang Penais, Zakat, dan Wakaf) yang kemudian disampaikan ke seluruh bidang di lingkungan kantor Setelah dana zakat profesi terhimpun melalui UPZ, dana tersebut disetorkan ke Baznas Provinsi Kalimantan Selatan.

Adapun kadar zakat profesi diqiyaskan dengan zakat emas yaitu 2,5\% dari seluruh penghasilan kotor dengan nishab sebesar 85 gram emas. Zakat profesi dibayarkan setiap bulan melalui bendahara gaji setelah dipotong pajak penghasilan. Jika menggunakan rata-rata harga emas Antam selama tahun 2018 dan 2019 dengan nilai per gram emas seharga Rp 676.000,- dan Rp 771.000,-. Dengan demikian nisab zakat profesi pada tahun 2018 sebesar Rp 57.460.000,-, dan pada tahun 2019 sebesar Rp 65.535.000,-. Pegawai yang dikenai wajib zakat atas penghasilannya adalah mereka yang memperoleh penghasilan setara atau lebih dari Rp 57.460.000,- dalam setahun, atau $\mathrm{Rp}$ 4.788.333,- dalam sebulan pada tahun 2018, dan memperoleh penghasilan setara atau lebih dari Rp 65.535.000,- dalam setahun atau Rp 5.461.250,- dalam sebulan pada tahun 2019. Dengan penghasilan rata-rata PNS golongan III di Kanwil Kemenag Kalimantan Selatan yakni Rp 5.663.870,- dikali dengan kadar zakat profesi sebesar 2,5\% maka besaran zakat profesi yang harus dibayarkan adalah senilai Rp 141.597,-per bulan.

Tabel 1. Nisab Zakat Profesi Tahun 2018-2019 Berdasar Harga Emas Antam

\begin{tabular}{cccc}
\hline Tahun & $\begin{array}{c}\text { Harga Emas } \\
\text { per gram (Rp) }\end{array}$ & $\begin{array}{c}\text { Nisab per } \\
\text { tahun (Rp) }\end{array}$ & $\begin{array}{c}\text { Nisab per } \\
\text { bulan (Rp) }\end{array}$ \\
\hline 2018 & 676.000 & 57.460 .000 & 4.788 .333 \\
\hline 2019 & 771.000 & 65.535 .000 & 5.461 .250 \\
\hline
\end{tabular}

Sumber: Data diolah

\footnotetext{
${ }^{35}$ Meriyati Meriyati, "Perkembangan Ekonomi Islam Pada Masa Daulah Abbasiyah," Islamic Banking : Jurnal Pemikiran dan Pengembangan Perbankan Syariah 4, no. 1 (14 Agustus 2018): 45-56, https://doi.org/10.36908/isbank.v4i1.54.
} 
Untuk mengetahui potensi penerimaan zakat di Kantor Wilayah Kementerian Agama Provinsi Kalimantan Selatan terlebih dahulu dilakukan screening atau melakukan seleksi jumlah Pegawai Negeri Sipil yang beragama Islam dan memiliki penghasilan minimal setara atau lebih dari nisab perbulan. Kemudian besaran zakat minimum diakumulasikan sesuai jumlah pegawai yang dikenai wajib zakat.

Tabel 2. Jumlah PNS Kanwil Kemenag Kalsel

\begin{tabular}{ccccccc}
\hline \multirow{2}{*}{ Tahun } & \multirow{2}{*}{ Jumlah } & \multicolumn{5}{c}{ Agama } \\
\cline { 3 - 6 } & & Islam & Kristen & Katolik & Hindu & Buddha \\
\hline 2018 & 131 & 123 & 2 & 2 & 2 & 2 \\
\hline 2019 & 131 & 123 & 2 & 2 & 2 & 2 \\
\hline
\end{tabular}

Sumber data: Kanwil Kemenag Provinsi Kalimantan Selatan

Dari data yang diperoleh, tidak ada PNS di Kanwil Kemenag Kalsel yang berpenghasilan dibawah nisab yang ditetapkan. Maka besaran potensi zakat profesi di lingkungan Kanwil Kemenag Kalimantan Selatan mencapai Rp 17.416.431,- per bulan atau Rp 208.997.172,- per tahun.

Tabel 3. Potensi Penerimaan Zakat Profesi

PNS Kanwil Kemenag Kalsel Tahun 2018

\begin{tabular}{ccc}
\hline $\begin{array}{c}\text { Kadar Zakat per Individu } \\
(\mathbf{R p})\end{array}$ & $\begin{array}{c}\text { Potensi Zakat Profesi } \\
\text { per Bulan (Rp) }\end{array}$ & $\begin{array}{c}\text { Potensi Zakat Profesi } \\
\text { per Tahun (Rp) }\end{array}$ \\
\hline 141.597 & 17.416 .431 & 208.997 .172
\end{tabular}

Sumber: data diolah

Adapun penerimaan zakat profesi yang diterima Unit Pengumpul Zakat Kantor Wilayah Kementerian Agama Kalimantan Selatan pada tahun 2018 berjumlah Rp 109.600.789,- dan pada tahun 2019 berjumlah Rp 113.480.380,-. Sedangkan penyaluran zakat pada tahun 2018 berjumlah Rp 109.502.000,- dan pada tahun 2019 berjumlah Rp 113.582.615,-.

Tabel 4. Penerimaan dan Penyaluran Zakat Profesi Kanwil Kemenag Kalsel

\begin{tabular}{ccc}
\hline Tahun & Penerimaan (Rp) & Penyaluran (Rp) \\
\hline Januari & 8.617 .918 & 8.618 .000 \\
\hline Februari & 8.517 .918 & 8.517 .000 \\
\hline Maret & 8.347 .918 & 8.348 .000 \\
\hline April & 8.087 .115 & 8.087 .000 \\
\hline Mei & 9.658 .115 & 9.659 .000 \\
\hline Juni & 9.628 .115 & 9.629 .000 \\
\hline Juli & 9.680 .615 & 9.581 .000 \\
\hline Agustus & 9.550 .615 & 9.551 .000 \\
\hline September & 9.410 .615 & 9.411 .000 \\
\hline Oktober & 9.410 .615 & 9.410 .000 \\
\hline November & 9.410 .615 & 9.410 .000 \\
\hline Desember & 9.280 .615 & 9.281 .000
\end{tabular}


Total
Sumber Data: Kanwil Kemenag Provinsi Kalimantan Selatan
Tabel 5. Penerimaan dan Penyaluran Zakat Profesi
Kanwil Kemenag Kalsel Tahun 2019

\begin{tabular}{ccc}
\hline Tahun & Penerimaan (Rp) & Penyaluran (Rp) \\
\hline Januari & 9.280 .615 & 9.281 .000 \\
\hline Februari & 9.280 .615 & 9.380 .000 \\
\hline Maret & 9.280 .615 & 9.280 .615 \\
\hline April & 9.315 .615 & 9.316 .000 \\
\hline Mei & 9.295 .615 & 9.296 .000 \\
\hline Juni & 9.295 .615 & 9.296 .000 \\
\hline Juli & 9.295 .615 & 9.296 .000 \\
\hline Agustus & 9.295 .615 & 9.296 .000 \\
\hline September & 9.847 .615 & 9.848 .000 \\
\hline Oktober & 9.847 .615 & 9.848 .000 \\
\hline November & 9.722 .615 & 9.723 .000 \\
\hline Desember & 9.722 .615 & 9.722 .000 \\
\hline Total & $\mathbf{1 1 3 . 4 8 0 . 3 8 0}$ & $\mathbf{1 1 3 . 5 8 2 . 6 1 5}$
\end{tabular}

Dari data di atas terjadi kesenjangan antara potensi zakat dengan dana zakat yang terhimpun. Penerimaan zakat profesi pada tahun 2018 sebesar 52,44\% dan pada tahun 2019 sebesar 54,29\% dari potensi yang ada.

Terdapat perbedaan antara pola perhitungan kadar zakat profesi yang penulis lakukan dengan yang UPZ Kanwil Kemenag Kalsel lakukan. Peneliti menggunakan besaran gaji pokok dan tunjangan, sedangkan UPZ Kanwil Kemenang Kalsel menghitung kadar zakat profesi berdasarkan besaran gaji pokok saja. Sehingga, kadar zakat yang dikeluarkan oleh PNS di lingkungan Kanwil Kemenag Kalsel cenderung lebih sedikit daripada yang penulis tetapkan.

Apabila perhitungan zakat profesi berdasarkan besaran gaji pokok saja maka secara nishab penghasilan para PNS di lingkungan Kanwil Kemenag Kalsel yang rata-rata golongan III tidak memenuhi syarat wajib zakat karena nominal gaji pokoknya belum mencapai nisab setara 85 gr emas. Mengingat harga rata-rata emas acuan pada tahun 2018 dan 2019 sudah mencapai Rp 676.000,- dan Rp 771.000,-. Bahkan harga emas per September 2020 yang ditetapkan oleh PT. Antam mengalami perubahan jauh lebih tinggi, yakni Rp 1.021.000,- per gramnya. Jika menggunakan pola perhitungan kadar zakat profesi yang dilakukan UPZ Kanwil Kemenag Kalsel, maka pendapatan PNS di lingkungan Kanwil Kemenag Kalsel akan semakin jauh dari nishab zakat profesi. Oleh sebab itu, perhitungan yang disarankan adalah beracuan pada gaji pokok dan total tunjangan yang diperoleh para pegawai.

\section{Problematika Implementasi Zakat Profesi}

Realisasi penerimaan zakat profesi yang dilakukan Unit Pengumpul Zakat Kanwil Kemenag Kalsel masih belum optimal, yakni hanya 52,44\% di tahun 2018 dan 54,29\% 
di tahun 2019. Tingkat penyerapan potensi zakat profesi yang masih rendah di Kanwil Kemenag Kalsel disebabkan karena pola perhitungan kadar zakat profesi yang beracuan pada gaji pokok saja dan tanpa memperhitungkan total tunjangan yang diperoleh pegawai. Sehingga, dengan perhitungan seperti ini besaran kadar zakat profesi yang dibayarkan pegawai pun jauh lebih sedikit. Ditambah lagi, perhitungan seperti ini menyebabkan perbedaan persepsi, yakni jika perhitungan berdasarkan besaran gaji pokok pegawai saat ini, maka untuk PNS yang berpangkat golongan III belum termasuk dalam wajib zakat profesi/pendapatan.

Faktor lain yang menyebabkan kurangnya penyerapan potensi zakat profesi di lingkungan Kanwil Kemenag Kalsel adalah masih ada pegawai yang belum mau membayarkan zakatnya melalui Unit Pengumpul Zakat dengan alasan belum memenuhi nishab zakat profesi yang ditetapkan dan lebih memilih menyerahkan secara langsung kepada Mustahik. Mereka beralasan lebih mengutamakan penyerahan zakat maupun sedekah kepada kerabat dan saudara terlebih dahulu dengan berpegang pada hadits yang diriwayatkan oleh An-Nasai nomor 2583:

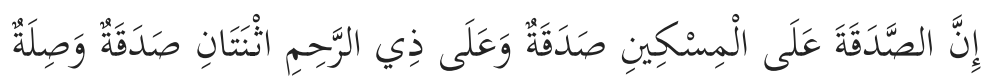

Artinya: "Sesunggubnya sedekah kepada orang miskin pahalanya satu sedekah, sedangkan sedekah kepada kerabat pahalanya dua; pabala sedekah dan pabala menjalin bubungan kekerabatan."

Temuan ini sejalan dengan hasil penelitian yang dilakukan oleh Pakaya dan Lahaji, yang menyebutkan bahwa pemahaman PNS tentang kewajiban zakat profesi masih beragam. Pemahaman ini berdampak pada tingkat kesadaran dan kepatuhan dalam membayar zakat, dalam hal ini BAZNAS, Pemerintah Daerah dan ulama hendaknya bersinergi dalam mensyiarkan zakat. ${ }^{36}$

Perbedaan penafsiran dalam implementasi zakat profesi masih menjadi perdebatan. Di antaranya terkait besaran nishab zakat profesi apakah mengikuti zakat emas atau zakat tanaman/perkebunan. Jika mengikuti zakat emas maka harus memenuhi haul (1 tahun), apabila mengikuti nisab tanaman/perkebunan maka dikeluarkan setiap memperoleh hasil. Sedangkan implementasi zakat profesi yang berlaku saat ini mengikuti nisab dan kadar emas kemudian dibayarkan setiap bulan atau setiap memperoleh penghasilan layaknya zakat pertanian. Hal serupa disebutkan dalam sebuah penelitian, dimana aturan main perhitungan potongan zakat profesi disebut tidak konsisten, karena nishabnya di-qiyas-kan dengan zakat tanaman tetapi yang dikeluarkan bukan dengan ukuran zakat tanaman melainkan dengan ukuran zakat emas yakni 2,5\%. Seharusnya, jika di-qiyas-kan dengan zakat tanaman maka yang dikeluarkan sebesar $5 \%$ atau $10 \% .^{37}$

Perbedaan penafsiran lainnya ada pada perhitungan nishab berdasarkan pendapatan kotor (bruto) atau pendapatan bersih (netto). Menurut Yusuf Qardhawi zakat profesi dapat dihitung melalui dua cara yaitu berdasarkan penghasilan kotor dan besih (bruto dan netto). Zakat profesi dihitung berdasarkan penghasilan kotor artinya mengeluarkan

\footnotetext{
36 Faisal Pakaya dan Lahaji Lahaji, "Implementasi Zakat Profesi terhadap Aparatur Sipil Negara di Pemerintah Daerah Kabupaten Bone Bolango," Al-Mizan, 2019, https://doi.org/10.30603/am.v15i1.977.

${ }^{37}$ Ali Trigiyatno, "Zakat Profesi antara Pendukung dan Penentangnya," Jurnal Hukum Islam IAIN Pekalongan 14, no. 2 (2016): 135-51.
} 
zakat langsung ketika menerima sebelum dikurangi apapun. Sedangkan zakat profesi dihitung berdasarkan penghasilan bersih, artinya mengeluarkan zakat dari harta yang masih mencapai nisab setelah dikurangi untuk kebutuhan pokok sehari-hari dan juga hutang. Jika penghasilan setelah dikurangi kebutuhan pokok masih mencapai nisab, maka orang tersebut termasuk wajib zakat. Tapi kalau tidak mencapai nisab maka tidak termasuk wajib zakat. ${ }^{38}$

Akibat kerancuan ini, lebih tepat jika zakat profesi bagi para pegawai disebut infak dan sedekah ketimbang disebut zakat. Untuk infaq dan sedekah besaran yang wajib dikeluarkan tidak ada ketentuan khusus melainkan atas dasar keikhlasan dan tidak menimbulkan konsekuensi hukum yang berat jika tidak dilaksanakan. Berbeda dengan zakat yang menimbulkan konsekuensi hukum berat jika ditidak dilaksanakan, sebab zakat termasuk dalam Rukun Islam.

Perbedaan persepsi tentang konsep zakat profesi menjadi pembahasan yang belum terjawab hingga sekarang. Para ulama sendiri masih berbeda pandangan tentang ada tidaknya zakat profesi, dan keduanya sama-sama memiliki alasan yang kuat. Akan tetapi, dengan hadirnya regulasi zakat di Indonesia melalui UU No. 23 Tahun 2011, Peraturan Pemerintah Republik Indonesia No. 14 Tahun 2014, Instruksi Presiden No. 3 Tahun 2014, hingga Surat Edaran Kepala Kanwil Kemenag Kalsel No. KW.17.6/BA.03.2/177/2016 dirasa sudah bisa menjadi alasan untuk para pegawai terlebih PNS dan ASN lainnya untuk taat atas aturan tersebut.

Salah satu kaidah fiqih yang erat kaitannya dengan pertentangan implementasi zakat profesi yakni

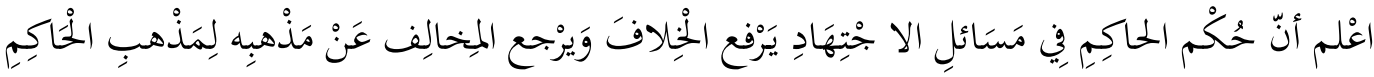

Artinya: Ketahuilah babwa keputusan/kebijakan seorang pemimpin/penguasa dalam berbagai persoalan ijtibad menutup pintu ikbtilaf (perbedaan pendapat). ${ }^{39}$

Oleh sebab itu, seharusnya dengan adanya berbagai macam peraturan yang diterbitkan pemerintah dapat menjadi acuan bagi setiap kalangan masyarakat untuk patuh dan melaksanakan apa yang diatur dalam aturan tersebut, di antaranya terkait implementasi zakat profesi di lingkungan pegawai pada umumnya dan Aparatur Sipil Negara khususnya.

Namun demikian, hingga saat ini regulasi terkait zakat profesi di Indonesia masih menjadi sekedar himbauan, bukan aturan yang bersifat mengikat selama masih terjadi perbedaan penafsiran. Memaksakan setiap orang untuk terikat dengan aturan yang masih menimbulkan perbedaan pendapat dapat memicu gelombang protes, sebab perbedaan penafsiran adalah perkara khilafiyah yang sama-sama didukung dengan dalil yang kuat serta pendapat-pendapat ulama dan ahli yang juga sama kuatnya. Jalan tengah yang dapat dilakukan agar regulasi zakat profesi dapat terimplementasikan secara optimal adalah dengan cara meningkatkan sosialisasi tentang keutamaan zakat, infaq dan sedekah.

\footnotetext{
38 BAZNAS, "Panduan Zakat,” https://baznas.go.id/panduanzakat, 2019.

${ }^{39}$ Ahmad bin Idris bin Abd al-Rahman al-Sanhaji Al-Qarafi, Anwar al-Buruq fi Anwa' al-Furuq, 2 ed. (Beirut: Alam al-Kutub, t.t.).
} 
Beberapa faktor yang mendorong Muzakki mau menyetorkan zakatnya melalui lembaga amil zakat yakni tingkat pendidikan, religiusitas, dan pendapatan Mustahik. ${ }^{40}$ Tingkat pendidikan atau pengetahuan berpengaruh terhadap pola pikir Mustahik, oleh sebab itu sosialiasi tentang aturan zakat profesi sangat penting untuk terus dilakukan. Begitu juga pemahaman Mustahik terkait nishab dan kadar zakat, karena erat pengaruhnya terhadap pendapatan Mustahik. Apabila Mustahik tidak memahami nishab dan kadar zakat profesi, maka ia tidak akan sadar ketika pendapatannya telah memenuhi 1 kali nishab yang mewajibkannya untuk menunaikan zakat. Dalam hal religiusitas, berhubungan dengan ketaatan Mustahik sebagai seorang hamba. Semakin tinggi tingkat religiusitas Mustahik maka ia semakin sadar tentang kewajiban zakat.

Perwujudan religiusitas seorang Mustahik tercermin dari cara ia menjalankan ibadah serta rasa percaya terhadap reputasi lembaga zakat yang diberi amanah. ${ }^{41}$ Oleh sebab itu Unit Pengumpul Zakat harus menjalankan tugasnya secara profesional. Keprofesionalan tersebut diukur dari sikap transparansi, sosialisasi, serta keteraturan administrasi sehingga preferensi Muzakki terhadap Lembaga Amil Zakat akan meningkat, ${ }^{42}$ yang kemudian juga memengaruhi loyalitas Muzakki untuk terus menunaikan zakat profesi. ${ }^{43}$

Tranparansi atau keterbukaan mengharuskan seorang Amil bersikap kredibel atau dapat dipercaya. Untuk melihat kredibilitas seseorang membutuhkan waktu yang tidak sebentar. Tidak hanya berdasarkan tampilan luar tetapi juga hasil dari pekerjaan merupakan salah satu hal yang dapat dijadikan penilaian kredibilitas. Sosialiasi dapat diartikan sebagai kemampuan komunikasi antara Amil dengan Muzakki. Kemampuan komunikasi yang efektif dan efisien agar dapat memengaruhi atau mengajak orang lain melakukan sesuatu yang baik, dan memberikan rasa nyaman. Keteraturan dalam administrasi artinya Amil handal dalam mengelola berbagai macam hal terkait penghimpunan maupun penyaluran dana zakat. Dengan adanya Amil yang handal dalam mengatur administrasi akan membuat Muzakki semakin yakin dan percaya terhadap kinerja Lembaga Amil Zakat dan menimbulkan kepuasan ketika berurusan pada waktu dan kondisi teretentu. ${ }^{44}$

\section{Penutup}

Melalui Surat Edaran No. KW.17.6/BA.03.2/177/2016 Kanwil Kemenag Kalsel menunjukkan keseriusannya dalam mengimplementasikan Zakat Profesi di lingkungan

40 A'yun, "Analisis Faktor Tingkat Pendidikan, Religiusitas dan Pendapatan Dalam Mempengaruhi Kepatuhan Individu Mengeluarkan Zakat Maal (Studi Kasus Pegawai di Kementerian Agama Malang).”

${ }^{41}$ Fery Setiawan, "Pengaruh Religiusitas, Kepercayaan, dan Reputasi terhadap Minat Muzzaki Dalam Membayar Zakat Profesi (Studi Kasus di Kabupaten Ponorogo)," JEP: KMEP Universitas Muhamadiyah Surakarta, 2017.

${ }^{42}$ Mukhlis dan Beik, "Analisis Faktor-faktor yang Memengaruhi Tingkat Kepatuhan Membayar Zakat: Studi Kasus Kabupaten Bogor.”

43 Andi Martina Kamaruddin, Zamruddin Hasid, dan Isna Yuningsih, "Faktor-faktor yang Mempengaruhi Keputusan Berzakat Profesi dan Loyalitas Muzzaki terhadap Laz Rumah Zakat Kota Samarinda," Jurnal Eksekutif, 2015.

44 Sutardi, Muhammad Irwan, dan Ihsan Ro’is, "Implementasi Kaidah-Kaidah Islam dalam Pengelolaan Zakat Profesi," Al Masraf: Jurnal Lembaga Keuangan dan Perbankan, 2017. 
kerjanya. Implementasi Zakat Profesi dilakukan dengan cara memberikan blanko kesediaan membayar zakat, infaq dan sedekah kepada seluruh pegawai. Kemudian, bagi pegawai yang bersedia akan langsung dipotong dari gaji setiap bulan oleh Unit Pengumpul Zakat (UPZ). Dana yang masuk melalui UPZ kemudian dibukukan dan diolah pelaporan serta ditanda tangani oleh Ketua UPZ (Kepala Bidang Penais, Zakat, dan Wakaf), kemudian laporan perbulan disampaikan ke seluruh bidang di lingkungan kantor. Setelah dana zakat profesi dikumpulkan melalui UPZ Kanwil Kemenag Kalsel, dana tersebut disetorkan 100\% ke BAZNAS Provinsi Kalimantan Selatan. Sedangkan untuk pendistribusian dilakukan sepenuhnya oleh BAZNAS Provinsi Kalimantan Selatan.

Dari potensi Zakat Profesi yang ada, realisasi penerimaan zakat profesi melalui UPZ Kanwil Kemenag Kalsel menunjukkan penyerapan yang masih belum optimal yakni sebesar 52,44\% di tahun 2018 dan 54,29\% di tahun 2019. Kurang optimalnya penyerapan potensi zakat profesi di lingkungan PNS Kanwil Kemenag Kalsel disebabkan adanya perbedaan penafsiran konsep zakat profesi, mulai dari besaran gaji pokok yang belum memenuhi nishab setara 85 gram emas, hingga perbedaan pendapat tentang perhitungan zakat profesi antara pendapatan bersih (netto) atau pendapatan kotor (bruto) setelah dikurangi kebutuhan pokok sehari-hari.

Guna mengoptimalkan potensi zakat profesi di lingkungan PNS Kanwil Kemenag Kalsel perlu suatu aturan yang mengikat bukan hanya sekedar himbuan. Unit Pengumpul Zakat selaku Amil juga dituntut untuk profesional guna membangun kepercayaan Muzakki. Profesionalitas Amil dapat diukur diukur dari sikap transparansi atau kredibilitas, sosialisasi atau kemampuan komunikasi, serta keteraturan administrasi yakni kehandalan Amil mengelola berbagai macam hal terkait penghimpunan maupun penyaluran dana zakat

Berdasarkan kesimpulan tersebut, penulis merekomendasikan kepada Unit Pengumpul Zakat Kanwil Kemenag Kalsel untuk meningkatkan sosialisasi tentang kewajiban zakat profesi kepada para pegawai serta menjelaskan regulasi yang berlaku saat sekarang, terutama terkait keputusan perhitungan kadar zakat atas berdasarkan penghasilan kotor. Selanjutnya, kajian ulang terhadap sistem perhitungan kadar zakat berdasarkan gaji pokok ditambah tunjangan yang diperoleh pegawai juga perlu dilakukan, agar tidak ada lagi pegawai yang beranggapan bahwa penghasilannya masih berada di bawah nishab zakat profesi. Terakhir, profesionalitas Amil yang bertugas di Unit Pengumpul Zakat perlu ditingkatkan, terutama dalam hal komunikasi. Ajakan untuk menunaikan zakat tidak cukup hanya menyebarkan blanko kesediaan, tetapi juga harus melalui pendekatan agar muzakki tertarik membayarkan zakatnya melalui Unit Pengumpul Zakat.

\section{Daftar Pustaka}

Al-Qarafi, Ahmad bin Idris bin Abd al-Rahman al-Sanhaji. Anwar al-Buruq fi Anwa' al-Furuq. 2 ed. Beirut: Alam al-Kutub, t.t.

A'yun, Alvira 'Aina. “Analisis Faktor Tingkat Pendidikan, Religiusitas dan Pendapatan Dalam Mempengaruhi Kepatuhan Individu Mengeluarkan Zakat Maal (Studi Kasus Pegawai di Kementerian Agama Malang)." Jurnal Ilmiah Mahasiswa FEB Universitas Brawijaya 5, no. 2 (2017).

Bank Indonesia, dan Fakultas Ekonomi UII. Pengelolaan Zakat Yang Efektif: Konsep dan Praktik di Beberapa Negara. Seri Ekonomi Dan Kenangan Syariah. Jakarta: Departemen Ekonomi dan Keuangan Syariah Bank Indonesia, 2016. 
BAZNAS. "Panduan Zakat.” https://baznas.go.id/panduanzakat, 2019.

Statistik. Zakat Nasional 2017. Badan Amil Zakat Nasional, 2018.

- “Zakat Penghasilan.” Diakses 10 Desember 2020. https://baznas.go.id/zakatpenghasilan.

Fakhruddin. Fiqh dan Manajemen Zakat di Indonesia. Malang: UIN-Maliki Pres, 2008.

Firdaus, Muhammad, Irfan Syauqi Beik, Tonny Irawan, dan Bambang Juanda. "Economic estimation and determinations of Zakat potential in Indonesia." IRTI Working Paper Series, 2012.

Hafizah, Yulia. Dimensi Normatif Ekonomi Islam: Penjelasan Seputar Ayat-Ayat Ekonomi Dalam Al-Qur'an. Yogyakarta: Kurnia Kalam Semesta, 2017.

Hassanain, Khalifa, dan Abd elrahman Elzahi Saaid. "Zakah for Poverty Alleviation: Evidence from Sudan.” International Research Journal of Finance and Economics, 2016.

Herfita Rizki Hasanah Gurning, dan Haroni Doli Hamoraon Ritonga. "Analisis Tingkat Kesdara Masyarakat Kecamatan Medan Baru Dalam Membayar Zakat." Jurnal Ekonomi Dan Keuangan 3, no. 7 (2015): 490-504.

Kamaruddin, Andi Martina, Zamruddin Hasid, dan Isna Yuningsih. "Faktor-faktor yang Mempengaruhi Keputusan Berzakat Profesi dan Loyalitas Muzzaki terhadap Laz Rumah Zakat Kota Samarinda." Jurnal Eksekutif, 2015.

Khoir, M. Masykur. Risalah Zakat. Kediri: Duta Karya Mandiri, 2016.

Majelis Ulama Indonesia. "Fatwa MUI Zakat Penghasilan.” Himpunan Fatwa MUI 3 (2003): $1-5$.

Meriyati, Meriyati. "Perkembangan Ekonomi Islam Pada Masa Daulah Abbasiyah." Islamic Banking : Jurnal Pemikiran dan Pengembangan Perbankan Syariah 4, no. 1 (14 Agustus 2018): 45-56. https://doi.org/10.36908/isbank.v4i1.54.

Mukhlis, Ahmad, dan Irfan Syauqi Beik. "Analisis Faktor-faktor yang Memengaruhi Tingkat Kepatuhan Membayar Zakat: Studi Kasus Kabupaten Bogor." AlMuzara'ab 1, no. 1 (2013): 83-106. https://doi.org/10.29244/jam.1.1.83-106.

Mursyidi. Akuntansi Zakat Kontemporer. Bandung: Remaja Rosdakarya, 2003.

Muslim Media. “Tafsir Ibnu Katsir.” Penajam Paser Utara: Google Play Store, 2017.

Nafiah, Lailiyatun. "Pengaruh Pendayagunaan Zakat Produktif Terhadap Kesejahteraan Mustahiq Pada Program Ternak Bergulir Baznas Kabupaten Gresik." el-Qist V, no. 01 (2015): 307-21.

Nopiardo, Widi. "Perkembangan Fatwa MUI Tentang Masalah Zakat." Jurnal Ilmiah Syariah 15, no. 1 (2016): 66-76.

Nurwati, Nurwati, dan Heni Hendrawati. "Zakat dan Upaya Mengentaskan Kemiskinan." Cakrawala: Jurnal Studi Islam 14, no. 1 (2019): 40-47. https://doi.org/10.31603/cakrawala.v14i1.2695.

Pakaya, Faisal, dan Lahaji Lahaji. "Implementasi Zakat Profesi terhadap Aparatur Sipil Negara di Pemerintah Daerah Kabupaten Bone Bolango." Al-Mizan, 2019. https://doi.org/10.30603/am.v15i1.977. 
Puskas BAZNAS RI. Indikator Pemetaan Potensi Zakat (IPPZ), 2019.

. "Ketentuan Dan Tata Cara Penghitungan Zaat Profesi/Penghasilan," no. 17/08/BR/VII/2017 (2017).

. Outlook Zakat Indonesia 2019. Jakarta: Pusat Kajian Strategis Badan Amil Zakat Nasional, 2019.

Qardawi, Yusuf. Fiqh Az-Zakah. Kedua. Mu'assisah Ar-Risalah, 1973.

—. Hukum Zakat. Disunting oleh Salman Harun, Didin Hafidhuddin, dan Hasanuddin. 7 ed. Bogor: Pustaka Litera AntarNusa, 2004.

Republik Indonesia. Undang-Undang Republik Indonesia No. 23 Tahun 2011 Tentang Pengelolaan Zakat (2011).

Salnatera. "Kitab 9 Imam.” Dalam Ensiklopedi Hadits. Google Play Store, 2015.

Sartika, Mila. "Pengaruh Pendayagunaan Zakat Produktif terhadap Pemberdayaan Mustahiq pada LAZ Yayasan Solo Peduli Surakarta." La_Riba, 2008. https://doi.org/10.20885/lariba.vol2.iss1.art6.

Setiawan, Fery. "Pengaruh Religiusitas, Kepercayaan, dan Reputasi terhadap Minat Muzzaki Dalam Membayar Zakat Profesi (Studi Kasus di Kabupaten Ponorogo)." JEP: KMEP Universitas Muhamadiyah Surakarta, 2017.

Sudibyo, Bambang. Prospek dan Tantangan Pembangunan Zakat 2019. Jakarta: BAZNAS, 2018.

Sutardi, Muhammad Irwan, dan Ihsan Ro'is. "Implementasi Kaidah-Kaidah Islam dalam Pengelolaan Zakat Profesi.” AlMasraf: Jurnal Lembaga Keuangan dan Perbankan, 2017.

Trigiyatno, Ali. "Zakat Profesi antara Pendukung dan Penentangnya." Jurnal Hukum Islam LAIN Pekalongan 14, no. 2 (2016): 135-51.

Utami, S., dan I. Lubis. "Pengaruh Pendayagunaan Zakat Produktif Terhadap Pemberdayaan Mustahiq di Kota Medan.” Jurnal Ekonomi dan Keuangan, 2014. 